\title{
Students' Communication Skills in Solving Mathematical Literacy Problems Based on Mathematical Abilities
}

\author{
Ilmus Samawati ${ }^{1 *}$, Ika Kurniasari ${ }^{2}$ \\ ${ }^{1,2}$ Universitas Negeri Surabaya \\ *ilmussamawati01@gmail.com
}

Received: November 2020; Accepted: December 2020; Published: January 2021

\begin{abstract}
This research aims to describe students' communication skills in solving mathematical literacy problems based on mathematical abilities. This research is qualitative descriptive research. The subjects in this research were 27 students of class VIII in one of SMP Swasta in Sidoarjo. Subjects were given a mathematics ability test to categorize the subject's mathematical abilities into high, medium, and low-levels. The research data were obtained from the results of mathematics literacy tests and interviews conducted by 3 selected subjects. The results showed that 1) students with high mathematical abilities have a medium category of communication skills because students can fulfill the indicators of expression, interpretation, use of notations/symbols, and evaluation with correct answers without complete reasons, 2) students with medium mathematical abilities have a medium category of communication skills because students can fulfill the expression and interpretation indicators with correct answers along with correct and clear reasons, fulfill the indicators of using notations/symbols with correct answers without complete reasons, but students do not fulfill the evaluation indicators, and 3) students with low mathematical abilities have a very low category of communication skills because students can fulfill the expression and interpretation indicators with wrong answers but there is a reason, fulfill the indicators of using notations/symbols with correct answers but no reason, but students do not fulfill the evaluation indicators.

Keywords: communication skills, written, mathematical literacy problems, mathematical abilities.
\end{abstract}

How to Cite: Samawati, I., \& Kurniasari, I. (2021). Students' Communication Skills in Solving Mathematical Problems Based on Mathematical Abilities. Journal of Medives: Journal of Mathematics Education IKIP Veteran Semarang, 5(1), 22-35. 


\section{INTRODUCTION}

Communication is one of the important things in the learning process because it can make learning more alive. This happens because of the social interaction between students and students, students and teachers, and with their environment. This statement is reinforced by the opinion of Sarwono \& Meinarno (2009) that communication can create reciprocal relationships. Besides, communication also plays an important role for students to be able to understand material concepts, solve problems, express thoughts, think critically, communicate with other parties, either verbally or in writing. However, to be able to communicate well, people need a language. Mathematics is a language that can also be used in communication. This is reinforced by Baroody's statement in (Pangastuti, Johan, \& Kurniasari, 2014; Nunun, 2012; Izwita, 2009) that mathematics is a language or tool that can be used to communicate ideas or ideas, precisely and concisely so that information can be conveyed.

Through communication, students can understand and interpret understanding of mathematical problems, not only calculation problems but also mathematical problems in everyday life. The ability to solve mathematical problems in everyday life is known as mathematical literacy skills (Sari, 2015). Based on the results of a survey conducted by the Program for International Student Assessment (PISA), Indonesian students' mathematical literacy skills are still low. This is because students are accustomed to doing routine questions so that when students are given mathematical literacy questions they will feel that the questions are difficult and students will give up (Hapsari, 2018).

Mathematical literacy problems in the process require a strong understanding of concepts to be able to connect mathematical concepts and problems to measure the ability to reason, solve problems and argue rather than measure memory and calculation skills. Therefore, mathematics literacy questions are known as questions that require high-level abilities because they require algorithms, reasoning, and indepth knowledge so that students have difficulty learning them in different contexts, this is confirmed by opinion (Hope, 2007; De Lange, 2003; Hughes, 2001). In this research, the content used for mathematical literacy problems is numeric because only some students can use their mathematical reasoning skills to solve the problems given to these questions.

Students' difficulties in understanding mathematical concepts and problems are caused by several factors, such as the level of mathematical abilities, communication skills, ability to express opinions, and self-confidence. Students with different mathematical abilities will have different ways of understanding problems in mathematics and also solving them (Liviananda \& Ekawati, 2019). Through these differences, the teacher can investigate the extent of mathematical understanding and the location of misconceptions in students so that it is necessary to classify students' mathematical abilities. According to 
Lutfiannisak \& Sholihah (2018) mathematical communication skills can be classified based on students' mathematical abilities, namely students' daily abilities in participating in the teaching and learning process. Mathematical skills that will be used in this research are divided into three, namely high, medium, and low levels.

However, some researches that tested mathematical communication skills in solving mathematical literacy problems not using any review or use other reviews. Whereas in this research, in this research aims to describe students' mathematical communication skills in solving mathematical literacy problems based of mathematical abilities.

This research is important for educators because it can be used as input in designing appropriate learning so that these mathematical communication skills can help students to improve achievement and learning outcomes in class.

\section{METHOD}

In this research, the data were analyzed qualitatively with a descriptive approach. This research was conducted from August to September 2020 and involved 27 students of class VIII-1 in one of SMP Swasta in Sidoarjo. The researcher gave a mathematical ability test to the 27 students to determine the level of mathematical ability of each student, then selected 3 students with high, medium, and low levels of mathematical ability based on the percentages shown in Table 1.
Table 1. Student Mathematics Ability Category

\begin{tabular}{lc}
\hline \multicolumn{1}{c}{ Category } & Percentage \\
\hline High & $75 \leq x \leq 100$ \\
Medium & $50 \leq x<75$ \\
Low & $0 \leq x<55$ \\
\hline
\end{tabular}

Table 2. Mathematics Ability Test Material

\begin{tabular}{llc}
\hline Number & Material & Quantity \\
\hline 1 & Proportion & 1 \\
2 & Social Arithmetics & 1 \\
3 & Lines and Angles & 1 \\
4 & Squares and Triangles & 1 \\
5 & Presentation of Data & 1 \\
& Total & 5 \\
\hline
\end{tabular}

The mathematics ability test contains 5 essay questions with the material in class VII even semester. They are listed in Table 2.

Furthermore, selected students were given a mathematical literacy test and semi-structured interviews to determine their writing skills. The literacy test contains 3 standard PISA essay questions with the contents of Quantity. Both tests and interviews are methods of collecting data by researchers.

Table 3. Communication Skills Indicators

\begin{tabular}{ll}
\hline Indicator & Description \\
\hline Expression & $\begin{array}{l}\text { Students are able to find } \\
\text { mathematical ideas (write } \\
\text { down what is known and } \\
\text { asked) in finding solutions to } \\
\text { problems given orally and in } \\
\text { writing }\end{array}$ \\
Interpretation & $\begin{array}{l}\text { Students are able to find } \\
\text { solutions (and conclusions) } \\
\text { from the problems given and } \\
\text { be able to convey them }\end{array}$ \\
Using & $\begin{array}{l}\text { Students are able to use } \\
\text { mathematical symbols to } \\
\text { notation/ }\end{array}$ \\
pymbols & $\begin{array}{l}\text { well } \\
\text { Students are able to re-check } \\
\text { the completion that has been } \\
\text { Evaluation }\end{array}$ \\
&
\end{tabular}


Literacy tests and interviews were conducted to determine students' written communication skills. This communication ability can be seen by observing several indicators such as Table 3 . Then, it can be continued by assessing the communication skills based on the assessment rubric made by Ramadhan $\&$ Minarti (2018) in Table 4.

Table 4. Item Scoring of Mathematical Communication Skills

\begin{tabular}{|c|c|}
\hline$\overline{\text { Score }}$ & $\begin{array}{l}\text { Mathematical Communication } \\
\text { Skills }\end{array}$ \\
\hline 0 & No answer \\
\hline 1 & $\begin{array}{l}\text { The answer is wrong but there is a } \\
\text { reason }\end{array}$ \\
\hline 2 & $\begin{array}{l}\text { The answer is almost correct (the } \\
\text { conclusion is not there or the } \\
\text { formula is right but the conclusion } \\
\text { is wrong or the answer is right the } \\
\text { reason is wrong) }\end{array}$ \\
\hline 3 & $\begin{array}{l}\text { The correct answer with not } \\
\text { complete reason or the answer is a } \\
\text { little wrong }\end{array}$ \\
\hline 4 & $\begin{array}{l}\text { The answer is correct with } \\
\text { correctly and clearly reason }\end{array}$ \\
\hline
\end{tabular}

To measure mathematical communication skills individually students use the following formula:

$$
P=\frac{X}{Y} \times 100
$$

where

$P=$ level of mathematical communication skills of each individual,

$X=$ total score obtained by individuals, $Y=$ maximum score of each individual.

Furthermore, the results of the percentage score of students' mathematical communication skills are categorized into very high, high, medium, low, very low categories. This category is converted by using a score conversion according to Nurkancana and Sunarta in (Arifani, Sunardi, \&
Setiawan, 2015) that can be seen in Table 5. Besides communication indicators, there are also quantitative literacy indicators such as Table 6 .

Table 5. Score Conversion

\begin{tabular}{lc}
\hline Category & Percentage \\
\hline Very High & $90 \leq P \leq 100$ \\
High & $80 \leq P<90$ \\
Medium & $65 \leq P<80$ \\
Low & $55 \leq P<65$ \\
Very Low & $P<55$ \\
\hline
\end{tabular}

Table 6. Quantitative Literacy Indicators

\begin{tabular}{ll}
\hline Indicator & Description \\
\hline Interpretation / & $\begin{array}{l}\text { The activity of reasoning with } \\
\text { data and describing } \\
\text { mathematical ideas }\end{array}$ \\
Calculation & $\begin{array}{l}\text { Efforts to perform or work on } \\
\text { calculations and manipulate } \\
\text { numbers in measurement }\end{array}$ \\
Application / & $\begin{array}{l}\text { Ability to make good } \\
\text { judgments and conclusions } \\
\text { Analysis }\end{array}$ \\
& $\begin{array}{l}\text { based on quantitative analysis } \\
\text { of data or the logic of existing } \\
\text { problems } \\
\text { Expressing quantitative } \\
\text { evidence (correct calculation } \\
\text { process) that supports this } \\
\text { given answer }\end{array}$ \\
\hline
\end{tabular}

The analysis stage is carried out after obtaining data collection from written test data and interviews. The results of the mathematical communication skills test and interviews were analyzed using indicators set by the researcher. First, the results are analyzed using quantitative literacy indicators to find out how students solve mathematical literacy questions. Then re-analyzed using indicators of mathematical communication skills to find out which category students belong to. The stages in data analysis include data reduction, data presentation, and verification. 


\section{RESULT AND DISCUSSION Result}

Based on the results of the mathematical ability test, the categories for the level of mathematical ability are shown in Table 7.

Table 7. Level of Mathematical Ability

\begin{tabular}{lll}
\hline Name & Category & Code \\
\hline SAM & High & ST \\
MAHR & Medium & SS \\
AP & Low & SR \\
\hline
\end{tabular}

There are also other codes, namely ILM for Mathematical Literacy Indicators and KKM for Mathematical Communication Ability. These results are also supported by the results of student interviews. The results of student work are as follow.

Based on Figure 1, it can be seen that in number $1 \mathrm{ST}$ has fulfilled several indicators of mathematical communication skills, namely ST can express the problems given because ST can express mathematical ideas on the problem by writing what is asked exactly but what is known is not quite right. ST formulates the problem by entering the sequence formula using symbols appropriately but it is not in accordance with what is asked in the problem. ST also writes conclusions by interpreting the mathematical ideas that ST has expressed at the beginning, but these conclusions do not answer the results of the formulation of ideas because they do not match what was asked. This can happen because actually, ST doesn't really understand how to solve it. This was revealed by ST in the interviews.

In number $1, \mathrm{ST}$ does not show complete written communication because ST cannot explain in detail how

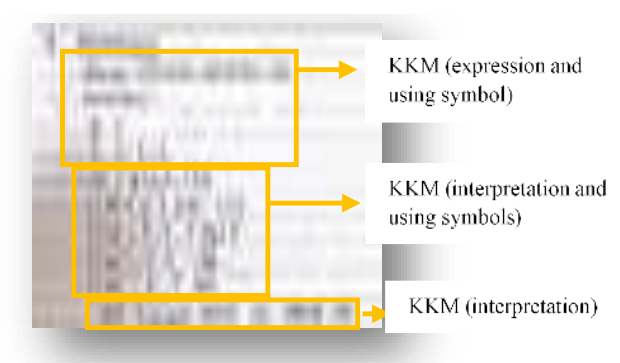

Figure 1. Answer ST in Number 1

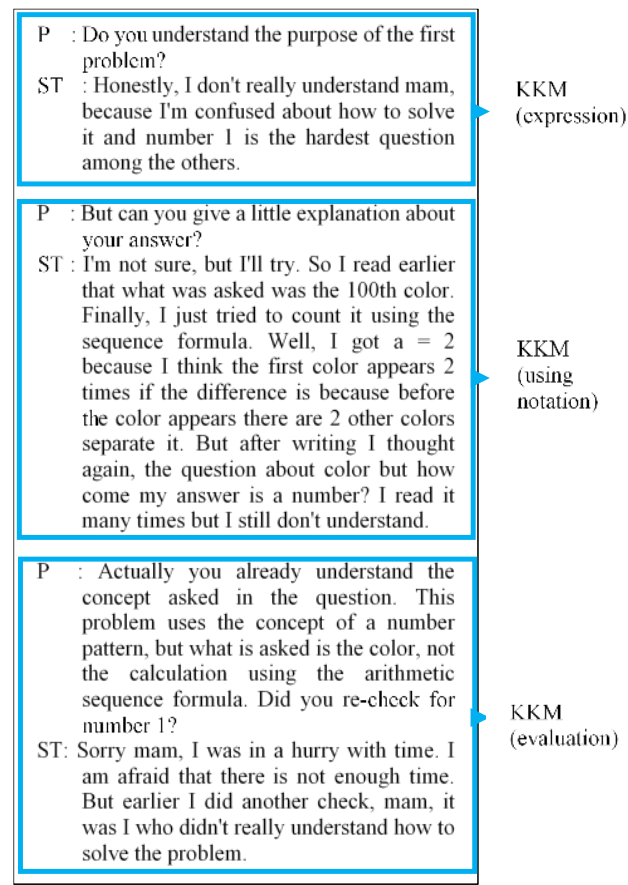

Figure 2. Interview ST in Number 1

it can solve the problem and does not provide an explanation in the form of an argument as reinforcement of the answers he wrote. However, ST has expressed the idea that he understands and has carried out an evaluation.

Based on Figure 3, it can be seen that in number $2 \mathrm{ST}$ has fulfilled several indicators of mathematical communication skills, namely ST can express the problems given because ST can express mathematical ideas on the problem by writing what is asked correctly but ST does not write what is known. ST formulates the problem in detail and according to what is asked in 


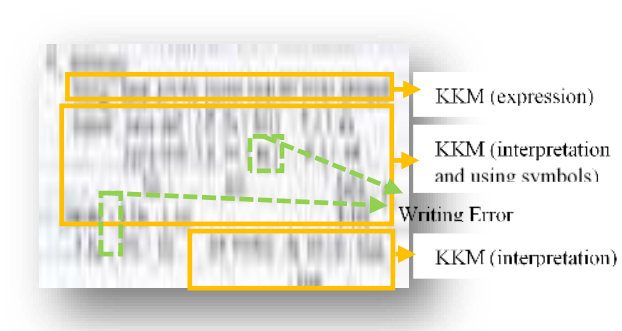

Figure 3. Answer ST in Number 2

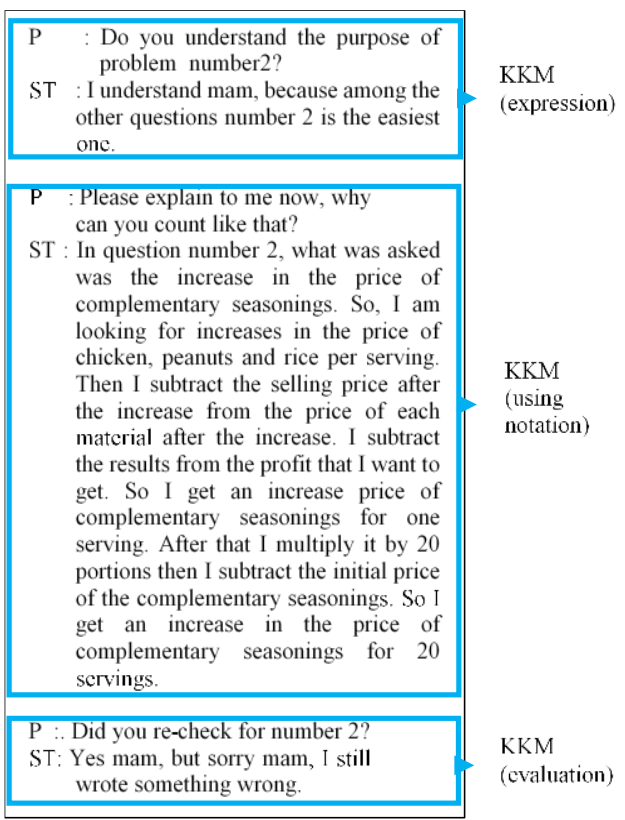

Figure 4. Interview ST in Number 2

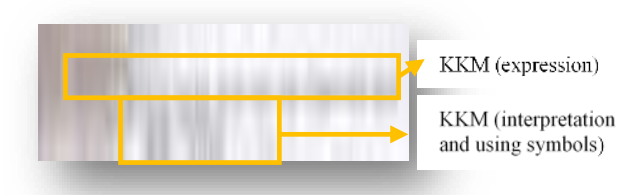

Figure 5. Answer ST in Number 3

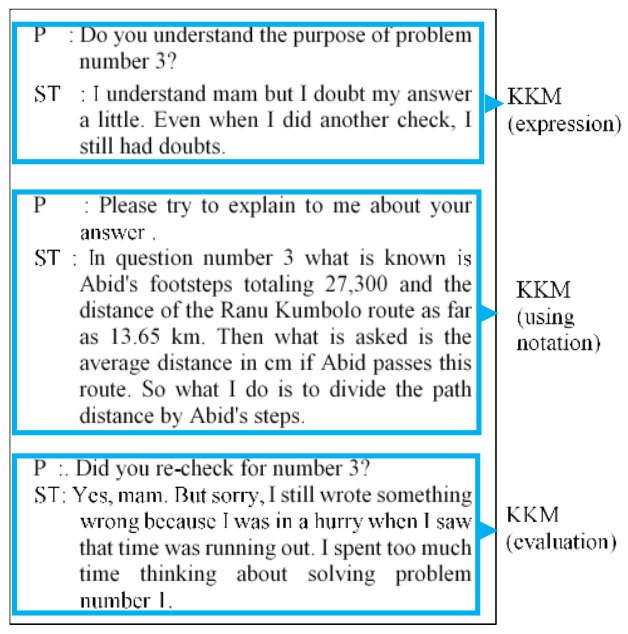

Figure 6. Interview ST in Number 3 problem number 2. ST also interprets the mathematical idea that ST has expressed at the beginning in the form of a conclusion but ST does not explain in the form of an argument as reinforcement of the answers he wrote. Besides, there was a writing error but ST didn't realize it. This was revealed by ST in the interviews the researchers conducted.

In number 2, ST also does not show complete written communication but ST explains in detail in the interview session. On completion in writing, ST can fulfill the indicators of communication skills, namely interpreting ideas, using notation, and evaluating the results of completion. Meanwhile, at the time of the interview, ST can fulfill all indicators of communication skills. This is different from number 1 because even ST in the interview session could not explain in detail.

Based on Figure 5, it can be seen that in number $3 \mathrm{ST}$ has fulfilled several indicators of mathematical communication skills, namely ST can express the problem given because ST can express mathematical ideas on the problem by writing down what is asked correctly but ST does not write what is known. ST formulates this problem by writing calculations but it is not what is asked for in problem number 3 because ST does not change the units first so ST does not find the answer and cannot write down the correct final unit. ST does not interpret the mathematical ideas that ST has expressed at the beginning in the form of conclusions, even arguments as reinforcement of the answers are also not written down. This was revealed by ST in the interviews. 
In number 3, ST also does not show complete written communication but ST can explain in detail during the interview session. On completion in writing, ST can fulfill the indicators of communication skills, namely interpreting ideas, using notation, and evaluating the results of completion. Meanwhile, at the time of the interview, the SR can fulfill all indicators of communication skills.

Of all ST's answers, none of them showed good written communication because it was by following ST's explanation during the interview session that ST could not manage the time to solve each question. ST spends too much time on questions that he considers difficult so that other problems cannot be solved properly. But ST's verbal communication is good enough because ST can explain in detail the problems in these questions and how to solve them.

Based on Figure 7, it can be seen that in number $1 \mathrm{SS}$ has fulfilled the indicator of mathematical communication skills, namely SS expresses the problem given because SS can express mathematical ideas on the problem by writing down what is asked and what is known exactly. SS formulated the problem by writing calculations in detail and according to what was requested in problem number 1. SS also interpreted the mathematical ideas that SS had expressed at the beginning in the form of conclusions. Not only that, but SS also added arguments to strengthen the answers he had written. However, at the time of the interview, SS was still unsure about several some many things. This was disclosed by SS as follows.

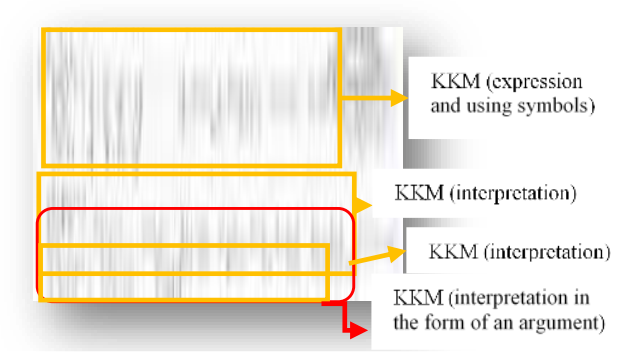

Figure 7. Answer SS in Number 1

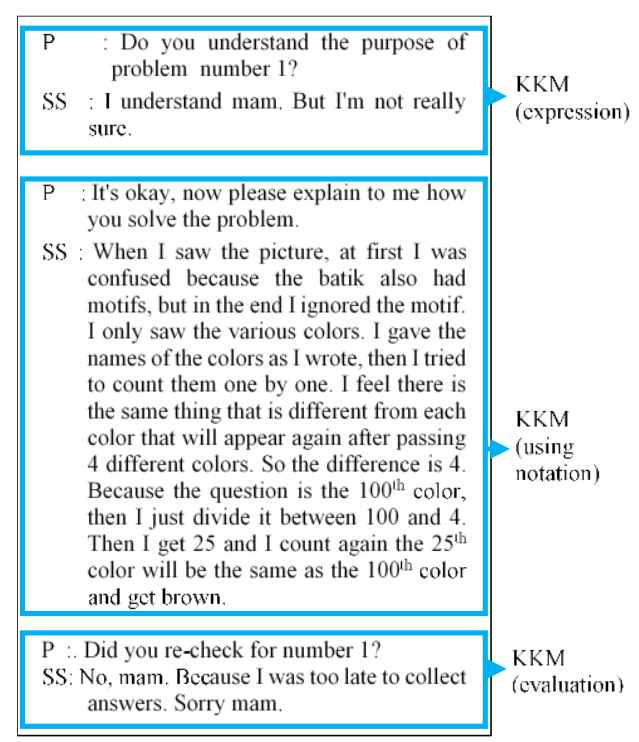

Figure 8. Interview SS in Number 1

SS does not fulfill the indicators of mathematical communication skills, namely evaluating by re-checking. The evaluation was not carried out on the result of completion in writing and was confirmed at the time of the interview that SS did not conduct an evaluation.

Based on Figure 9, it can be seen that in number $2 \mathrm{SS}$ has fulfilled the indicator of mathematical communication skills, namely SS expresses the problem given because SS can express mathematical ideas on the problem by writing down what is asked and what is known exactly. SS formulated the problem by writing calculations in detail and according to what was asked for in problem number 2. SS also interpreted 


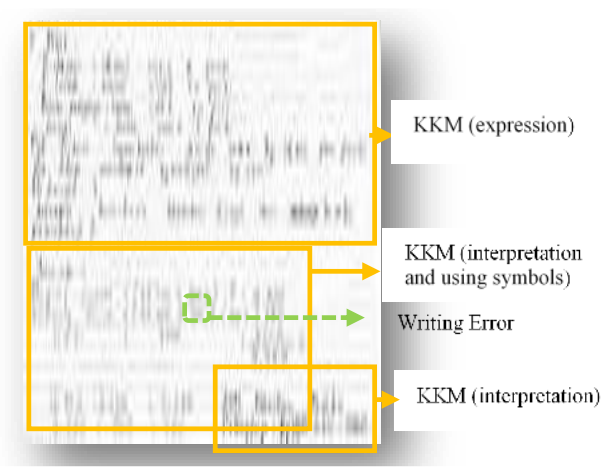

Figure 11. Answer SS in Number 2

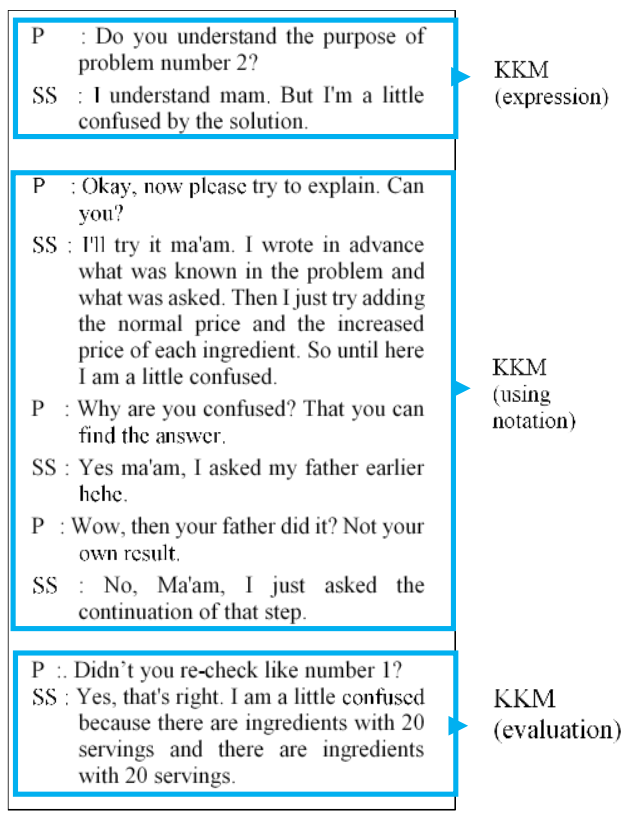

Figure 12. Interview SS in Number 2

the mathematical ideas that SS had expressed at the beginning in the form of conclusions, but SS did not provide an explanation in the form of arguments as reinforcement of the answers he wrote as already he did it at number 1 . In number 2 there was also a writing error and SS realized it during the interview session. This was disclosed by SS as follows.

In number 2, SS did not show complete written communication as in number 1. SS also could not explain in detail in the interview session because SS admitted that he was assisted by his father to solve the problem. SS does not

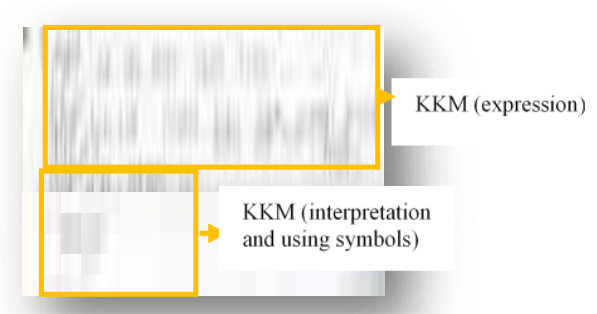

Figure 9. Answer SS in Number 3

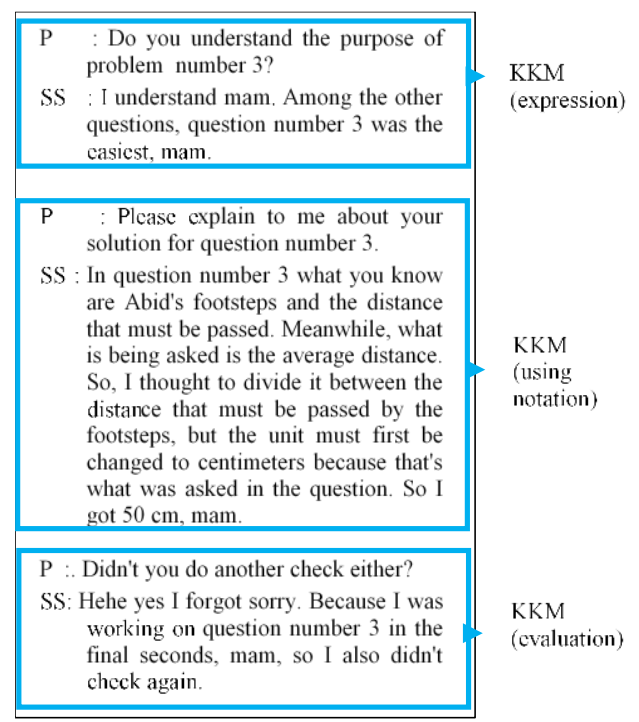

Figure 10. Interview SS in Number 3

fulfill the indicators of mathematical communication skills, namely evaluating by re-checking.

Based on Figure 11, it can be seen that in number $3 \mathrm{SS}$ has fulfilled several indicators of mathematical communication skills, namely the SS statement which is presented because SS can express mathematical ideas on the problem with what questions are asked and what is known exactly. SS formulated the problem with the calculation conflict in detail and according to what was related to problem number 3. However, SS did not interpret 
the mathematical idea that SS had expressed at the beginning in the form and SS did not provide an explanation in the form of an argument as an answer which he wrote as an explanation in the form argument which he has done at number 1. It is business by SS as follows.

At number 3, SS does not show complete written communication as in the previous number. SS also could not explain in detail the results of the completion on the answer sheet. SS does not fulfill the indicators of mathematical communication skills, namely evaluating by double-checking.

Of all the answers, the SS did not show proper written communication because the SS did not double-check every answer. However, SS's oral communication was good enough because SS could explain in detail the problems contained in the question and how to solve it except for number 2. This could happen because SS did not solve the problem itself.

Based on Figure 13, it can be seen that in number $1 \mathrm{SR}$ has fulfilled several indicators of mathematical communication skills, namely SR expresses the problem given because SR can express mathematical ideas on the problem by writing down what was asked but SR did not write what was asked. SR also did not write calculations. However, SR interprets the mathematical idea that SR has expressed at the beginning in the form of a conclusion and SR provides an explanation in the form of an argument as reinforcement of the answer he wrote. This was disclosed by SR as follows.

In number 1, SR does not indicate complete written communication. SR

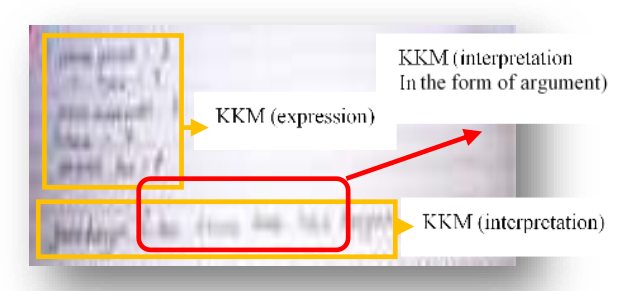

Figure 13. Answer SR in Number 1

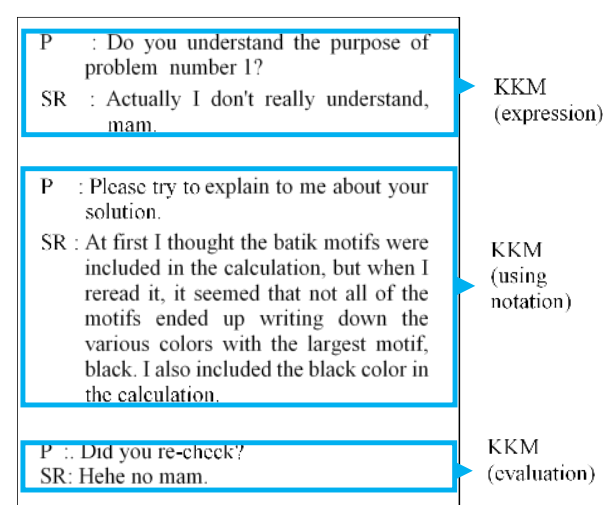

Figure 14. Interview SR in Number 1

also cannot explain in detail the results of the solution on the answer sheet. SR does not fulfill the indicators of mathematical communication skills, namely evaluating by re-checking and using symbols or notations or terms to present ideas.

Based on Figure 15, it can be seen that in number 2 SR has fulfilled several indicators of mathematical communication skills, namely SR can apply SR understanding through questions into written form. SR understands the meaning of the problem but he does not understand how to write it so SR does not write down what is known and asked as well as calculations. SR can do calculations but SR does not understand the detailed writing so SR only writes down the final result. However, the SR explanation is in the form of an argument to reinforce the answers he wrote. This was disclosed by SR as follows. 


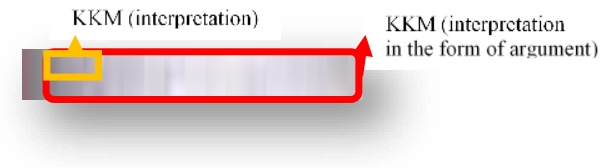

Figure 15. Answer SR in Number 2

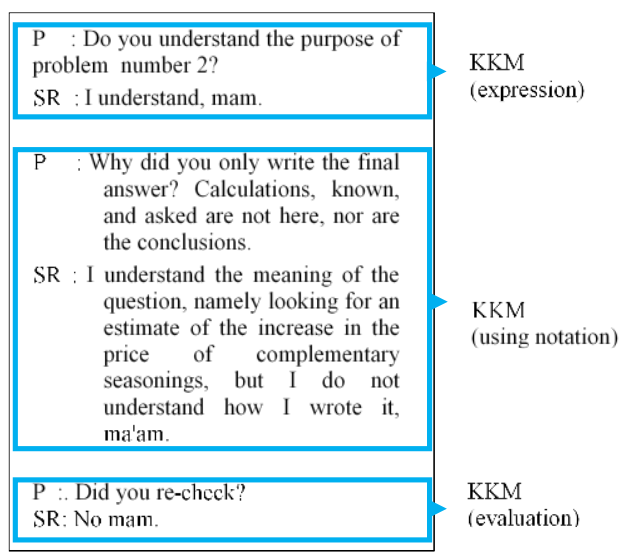

Figure 16. Interview SR in Number 2

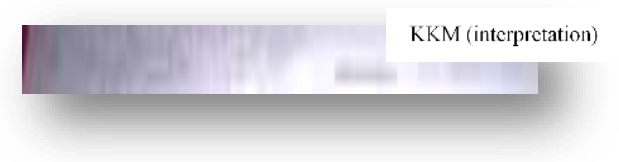

Figure 17. Answer SR in Number 3

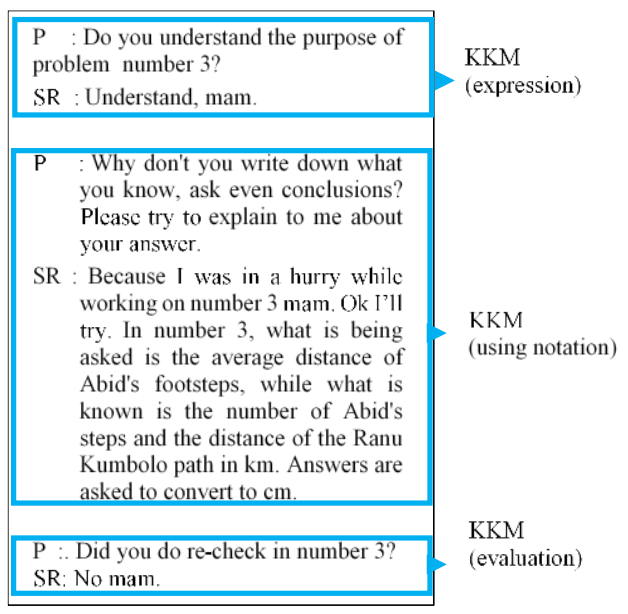

Figure 18. Interview SR in Number 3

In number 2, SR does not show complete written communication. SR gave an argument from the answer he wrote but the argument was wrong because SR did not understand how to solve the problem. SR does not fulfill the indicators of mathematical communication skills, namely expressing ideas, evaluating by re-checking, and using symbols or notations or terms to present ideas.

Based on Figure 17, it can be seen that in number $3 \mathrm{SR}$ has fulfilled the indicator of mathematical communication skills, namely SR formulates the problem by writing calculations even though the answer is still not quite right. SR did not write down the known, asked, conclusions, and SR did not provide reasons or arguments for the answer. This was disclosed by SR as follows.

In number 3, SR does not show complete written communication. This happens because the SR does not fulfill the indicators of mathematical communication, namely the statement of ideas, the use of symbols, and research by re-checking.

From all the answers, SR did not show written communication well because SR did not state the idea well, did not interpret the idea, did not use symbols or not or terms, and did not recheck every answer. However, SR's oral communication was good enough because SR was able to explain even though it was not detailed about the problems contained in the questions and how to solve them.

\section{Discussion}

Based on the results of student work, the scores of each student can be written to determine the category of students' communication skills in solving mathematical literacy questions based on the scoring guidelines mentioned in Table 4. 
Table 8. Student Work Results

\begin{tabular}{|c|c|c|c|c|c|}
\hline \multirow{2}{*}{$\begin{array}{l}\text { Question } \\
\text { Number }\end{array}$} & & \multirow{2}{*}{ Aspect } & \multicolumn{3}{|c|}{ Score } \\
\hline & & & ST & SS & SR \\
\hline \multirow{4}{*}{1} & \multirow{12}{*}{ 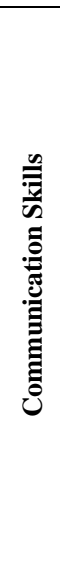 } & Expression & 3 & 4 & 2 \\
\hline & & Interpretation & 2 & 4 & 2 \\
\hline & & Using & 3 & 4 & 2 \\
\hline & & $\begin{array}{c}\text { symbols/notation } \\
\text { Evaluation }\end{array}$ & 2 & 0 & 0 \\
\hline \multirow{4}{*}{2} & & Expression & 3 & 4 & 0 \\
\hline & & Interpretation & 4 & 4 & 2 \\
\hline & & Using & 3 & 3 & 1 \\
\hline & & $\begin{array}{l}\text { symbols/notation } \\
\text { Evaluation }\end{array}$ & 3 & 0 & 0 \\
\hline \multirow{7}{*}{3} & & Expression & 3 & 4 & 0 \\
\hline & & Interpretation & 3 & 3 & 1 \\
\hline & & Using & 3 & 4 & 3 \\
\hline & & $\begin{array}{c}\text { symbols/notation } \\
\text { Eyaluation }\end{array}$ & 2 & 0 & 0 \\
\hline & & TOTAL & 34 & 34 & 13 \\
\hline & & TAL SCORE & & 48 & \\
\hline & & ATEGORY & $\mathbf{M}$ & $\mathbf{M}$ & VL \\
\hline
\end{tabular}

In Table 8, you can see the difference in scores for the three subjects. The assessment is based on the results of the mathematical literacy written test and is supported by the results of the interview as a compliment.

Students with a high level of mathematical ability have a moderate level of mathematical communication skills because students can fulfill all indicators of communication skills even though they are not completely fulfilled. If you look only at the results of the mathematical literacy written test, the ST score will not be like that but because of the interview as a supporter, the ST score is better. ST's written communication skills are not as good as their oral communication skills. In written communication, ST does not express the idea of each question and some are not given conclusions. However, during the interview (oral communication) ST was able to express ideas, interpret ideas, use notation or symbols, and evaluate each question. In written communication, ST is only able to fulfill three indicators with imperfect scores because of all the questions there is no ST answer that gets a perfect score. These indicators are expressing ideas, interpreting ideas, and using notations or symbols. In oral communication, ST can fulfill all indicators even though the score is still not perfect.

Students with a moderate level of mathematical ability have a moderate level of mathematical communication because students can fulfill all indicators of communication skills even though they are not completely fulfilled. If you look only at the results of the written mathematical literacy test, the SS score will not be like that but because of the interview as a supporter, the SS score becomes normal. SS written communication skills are different from their oral communication skills. In written communication, SS can express every idea well even though SS does not interpret the idea in all questions. However, during the interview (oral communication) SS only realized that there were several mistakes, SS also said that he did not solve the problems himself but received help from his parents, and SS also did not evaluate each problem. In written communication, SS can fulfill three indicators with almost perfect scores because SS can answer all the questions correctly. These indicators are expressing ideas, interpreting ideas, and using notations or symbols. In oral communication, SS did not fulfill one indicator, namely evaluating mathematical ideas by doing a re-examination because SS did not do that for all its solutions. 
Students with a low level of mathematical ability have a very low level of mathematical communication skills because students are less able to fulfill all indicators of communication skills both written and oral. In written communication, the SR did not write completely on the answer sheet so that on each problem there were indicators that were not fulfilled. In oral communication, SR is also unable to express and interpret his ideas because SR is still shy and does not really understand the meaning of the problem. SR also did not re-check for all its resolutions.

These results indicate that students' mathematical communication skills are influenced by the level of mathematical ability and also several other factors. So that students with high mathematical abilities and students with moderate mathematical abilities have the same score. Meanwhile, students with low math ability have the smallest score. Other factors such as duration of processing time, strategy setting, and a sense of confidence in students.

This is different from the findings in the research of Meiliyah and Setianingsih (2019). In this study, it was stated that students with high mathematical abilities were able to fulfill all communication indicators, students with moderate mathematical abilities were able to fulfill some of the communication indicators, and students with low mathematical abilities were only able to fulfill one communication indicator. Meanwhile, the linkage of other factors is strengthened by the findings in research conducted by
Liviananda \& Ekawati (2019), which is that there is a very strong relationship between student beliefs about mathematics and learning and math abilities.

\section{CONCLUSION}

Based on the results and discussion, it can be concluded that students' communication skills are in line with students' mathematical literacy. This is influenced by the level of mathematics ability of each student. Students with high mathematical abilities have a medium category of medium communication skills because students can fulfill the indicators of expression, interpretation, use of notations/symbols, and evaluation with correct answers without complete reasons. Students with medium mathematical abilities have a medium category of communication skills because students can fulfill the expression and interpretation indicators with correct answers along with correct and clear reasons, fulfill the indicators of using notations/symbols with correct answers without complete reasons, but students do not fulfill the evaluation indicators. Students with low mathematical abilities have a very low category of communication skills because students can fulfill the expression and interpretation indicators with wrong answers but there is a reason, fulfill the indicators of using notations or symbols with correct answers but no reason, but students do not fulfill the evaluation indicators. This can be seen in the scores obtained by students, students with high and medium mathematical 
abilities have the same communication skills score but both differ in the results of the mathematical literacy tests.

Therefore, for further research, it is suggested that other researchers can develop this research, especially for students with low math abilities to improve students' mathematical communication skills. It will be useful for the teacher to know the profile of students' mathematical communication skills and to add a PISA equivalent set of questions.

\section{REFERENCES}

Arifani, N. H., Sunardi, \& Setiawan, S. (2015). Tingkat Kemampuan Berpikir Kreatif Matematika Siswa SMP Kelas VIII Di SMP Negeri 6 Jember, SMP Al Furqan 1, SMP Negeri 1 Rambipuji, Dan SMP PGRI 1 Rambipuji. Jurnal Kadikma, 6, 159-172.

De Lange, J. (2003). Mathematics for Literacy. In B. L. Madison \& L. A. Steen (Eds.), Quantitative literacy: Why Numeracy Matters for Schools and Colleges. National Council on Education and the Disciplines, 75-89.

Hapsari, T. (2018). Literasi Matematis Siswa. Jurnal Euclid, 84-94.

Hope, M. (2007). Mathematical Literacy. Principal Leadership, 28-31.

Hughes, D. H. (2001). Achieving Numeracy: The Challenge of Implementation. In Mathematics and Democracy: The Case for Quantitative Literacy. National Council on Education and the Disciplines, 93-98.

Izwita, D. (2009). Profil Komunikasi Matematika Mahasiswa Calon
Guru Ditinjau dari Perbedaan Jenis Kelamin.

Liviananda, F., \& Ekawati, R. (2019).

Hubungan Keyakinan Siswa

Tentang Matematika dan

Pembelajarannya dengan

Kemampuan Matematika.

MATHEdunesa Jurnal Ilmiah

Pendidikan Matematika, 357-364.

Lutfiannisak, \& Sholihah, U. (2018).

Kemampuan Komunikasi

Matematis Siswa dalam

Manyelesaikan Soal Materi

Komposisi Fungsi Ditinjau dari

Kemampuan Matematika. Jurnal

Tadris Matematika, 1-8.

Mailiyah, A., \& Setianingsih, R. (2019).

Profil Komunikasi Matematis

Tulis Siswa SMP Dalam

Memecahkan Masalah

Matematika Ditinjau Dari

Perbedaan Kemampuan

Matematika. MathEduNesa, 8, 318-327.

Nunun, E. (2012). Meningkatkan Kemampuan Komunikasi Matematika Siswa Sekolah Menengah Pertama Melalui Pembelajaran Think-Talk-Write (TTW). Jurnal Ilmiah Program Studi Matematika STKIP Siliwangi Bandung, 178-185.

Pangastuti, L., Johan, A., \& Kurniasari, I. (2014). Profil Kemampuan Komunikasi Matematika Siswa SMP Ditinjau Dari Kecerdasan Emosional Lutvina. MATHEdunesa Jurnal Ilmiah Pendidikan Matematika, 127-133.

Ramadhan, I., \& Minarti, E. D. (2018). Kemampuan Komunikasi Matematika Siswa SMP dalam Menyelesaikan Soal Lingkaran. Journal of Medives: Journal of Mathematics Education IKIP Veteran Semarang, 151-161. 
Sari, R. H. (2015). Literasi Matematika: Apa, Mengapa dan Bagaimana? Seminar Nasional Matematika dan Pendidikan Matematika (hal. 713720). Yogyakarta: UNY.

Sarwono, E. A., \& Meinarno. (2009). Psikologi Sosial. Jakarta: Slemba Humanika. 